\title{
Effect of Exogenous Phytase on the Phosphorus and Zinc Metabolism of Fattening Bulls
}

\author{
Laura Winter \\ Institute of Animal Nutrition, Friedrich-Loeffler-Institute (FLI) \\ Federal Research Institute for Animal Health, Braunschweig, Germany \\ Tel: 49-531-596-3151Ｅ-mail: laura.winter@ fli.bund.de
}

Ulrich Meyer (Corresponding author)

Institute of Animal Nutrition, Friedrich-Loeffler-Institute (FLI)

Federal Research Institute for Animal Health, Braunschweig, Germany

Tel: 49-531-596-3137Ｅ-mail: Ulrich.meyer@fli.bund.de

\section{Liane Hüther}

Institute of Animal Nutrition, Friedrich-Loeffler-Institute (FLI)

Federal Research Institute for Animal Health, Braunschweig, Germany

Tel: 49-531-596-3128Ｅ-mail: Liane.huether@ fli.bund.de

\section{Peter Lebzien}

Institute of Animal Nutrition, Friedrich-Loeffler-Institute (FLI)

Federal Research Institute for Animal Health, Braunschweig, Germany

E-mail: Peter.lebzien@fli.bund.de

\section{Sven Dänicke}

Institute of Animal Nutrition, Friedrich-Loeffler-Institute (FLI)

Federal Research Institute for Animal Health, Braunschweig, Germany

Tel: 49- 531-596-01 E-mail: Sven.daenicke@ fli.bund.de 
Received: October 1, 2013 Accepted: October 21, 2013

doi:10.5296/jbls.v5i1.4354

URL: http://dx.doi.org/10.5296/jbls.v5i1.4354

\begin{abstract}
This study investigated the effects of exogenous phytase, different dietary phosphorus (P) and zinc (Zn) levels on the P- and Zn-metabolism of fattening bulls.

48 German Holstein bulls (average initial live weight $312 \pm 49 \mathrm{~kg}$ ) were used for a feeding trial and allocated to four dietary treatments, $\mathrm{P} / \mathrm{Zn}, \mathrm{P}+\mathrm{MIN} / \mathrm{Zn}, \mathrm{P} / \mathrm{Zn}+\mathrm{PHY}$ and P/Zn+MIN. All bulls received a diet of $80 \%$ corn silage and $20 \%$ concentrate on a dry matter (DM) basis. The corn silage intake was for ad libitum and the concentrate intake restricted.
\end{abstract}

The concentrate of $\mathrm{P}+\mathrm{MIN} / \mathrm{Zn}$ was supplemented with dicalcium phosphate. The concentrate of the P/Zn+PHY group was supplemented with an exogenous phytase $(0.1 \mathrm{~g} / \mathrm{kg} \mathrm{DM}$ in the diet, $50000 \mathrm{FTU} / \mathrm{g}$ ) and the concentrate of the P/Zn+MIN group was supplemented with Zn. The Pand $\mathrm{Zn}$-concentration in the diet of the P/Zn-, P+MIN/Zn-, P/Zn+PHY- and P/Zn+MIN-groups were 2.41, 2.99, 2.48 and $2.41 \mathrm{~g} \mathrm{P} / \mathrm{kg} \mathrm{DM}$ and 33.2, 33.6, 34.0 and $38.8 \mathrm{mg} \mathrm{Zn/kg} \mathrm{DM,}$ respectively.

No differences in $\mathrm{P}$ - and Zn-concentration of faeces, liver, testes and performance were observed between the treatments. In the Os metacarpale, $\mathrm{P}$ - and phytase supplementation resulted in a slightly higher $\mathrm{P}$-concentration, while the $\mathrm{Zn}$ addition led to the lowest value $(P=0.062)$. Overall, it becomes clear that the microbial phytase of the rumen is sufficient enough to make the indigestible phytate- $\mathrm{P}$ and the hardly digestible $\mathrm{Zn}$ digestible for ruminants. The supplemented dietary phytase has no influence on the bioavailability of the mineral $\mathrm{P}$ and the trace element $\mathrm{Zn}$.

Keywords: Phytase, Ruminants, P-metabolism, Zn-metabolism

\title{
1. Introduction
}

Phytase releases phosphorus (P) from inositol phosphate (InsP) by hydrolysis (Suttle, 2010). P from phytate is suggested to be highly available to ruminants because of the microbial phytase activity in the rumen (Clark et al., 1986; Morse et al., 1992). However, ruminal P-excretion with faeces seems to be linear to P-concentration in the diet of ruminants (Call et al., 1987; Suttle, 2010). Although ruminants generally have the ability to use phytin-bound phosphorus through ruminal hydrolysis, different studies showed that the dietary supplementation of exogenous phytase leads to reduced faecal excretion and an increased P-concentration in bones. However, not only $\mathrm{P}$ is bound to phytin but also trace elements such as zinc $(\mathrm{Zn})$ are known to be released by the action of exogenously added phytase in monogastric animals (Garikipati \& Kincaid, 2004). If such effects occur in ruminants is not known. Additionally phytase mediated release of these trace elements might increase their bioavailability.

$\mathrm{Zn}$ deficiency in the animals may occur due to different reasons. The first one is the primary deficiency because of an inadequate content in the diet of the animal. The secondary deficiency is caused by other elements that might hamper the Zn-absorption (Adeola et al., 1995). Because 
of this in the actual study it has to be taken into account that metal cations, such as $\mathrm{Zn}$ form insoluble complexes with phytate, which decrease the enzymatic rate of hydrolysis by phytase (Garikipati \& Kincaid, 2004). P-supplementation might result in Zn-deficiency symptoms as high concentrations of phytate in diets may lead to insoluble complexes of phytic-acid and $\mathrm{Zn}$ which are poorly available (Kirchgessner et al., 1994). Kornegay (2001) also described the influence of phytase on the $\mathrm{Zn}$ bioavailability in pig, poultry and fish diets and emphasized that $\mathrm{Zn}$ is closely connected to the phytate complex. Another important aspect of $\mathrm{Zn}$ in the feeding is that $\mathrm{Zn}$ is indispensable for the fertility of cattle (Van Laar \& Jongbloed, 2010). A study with rats showed that $\mathrm{Zn}$ is important for the spermatogenesis and that testes exhibit a high concentration of $\mathrm{Zn}$. Feeding rats with a low $\mathrm{Zn}$ diet resulted in lower weight of testes, epididymis and dorsal prostate (Millar et al., 1958). Not only rats were effected by Zn-deficiency, but also male goats showed reductions in testicular size and loss of libido (Neathery et al., 1973). Previous studies (Barney et al., 1968; Millar et al., 1958; Neathery et al., 1973) comprise investigations in rats and goats but not in bulls.

Thus one aim of the present experiment was to elucidate the effects of exogenous phytase, $\mathrm{Zn}$ and $\mathrm{P}$ on $\mathrm{P}$ - and $\mathrm{Zn}$-status of growing bulls. Therefore it is appropriate to examine the P-and $\mathrm{Zn}$-levels in liver, testes and bones to consider this when the results are evaluated. A further important point is to investigate the effect on the $\mathrm{P}$ - and $\mathrm{Zn}$-concentration of faeces of the bulls. Do the animals differ in their $\mathrm{P}$ - and $\mathrm{Zn}$-concentration if reduced or higher amounts of minerals are fed and if there is an exogenous phytase in the feed?

For this reason, a $\mathrm{P}$ - and $\mathrm{Zn}$-reduced diet should be compared to a full supplied diet and a $\mathrm{P}$-and Zn-reduced diet added with phytase. Feeding these four different treatments, it becomes possible to figure out if a supplemented enzyme is able to compensate a deficiency by splitting up more indigestible $\mathrm{P}$-and $\mathrm{Zn}$-complexes than the rumen microbes do, and to figure out if phytase supplementation in combination with a reduced level of $\mathrm{P}$ and $\mathrm{Zn}$-intake has effects on the performance and the $\mathrm{P}$ and $\mathrm{Zn}$-concentration in faeces and bones.

\section{Materials and Methods}

\subsection{Animals and Experimental Design}

The experiment with 48 German Holstein bulls was carried out at the experimental station of the Institute of Animal Nutrition, Friedrich-Loeffler-Institute (FLI), Federal Research Institute for Animal Health, in Braunschweig, Germany. The animals were randomly assigned based on age and body weight to one of four experimental groups of 12 animals each. At the beginning of the trial, the bulls had a mean body weight of $312 \pm 49 \mathrm{~kg}$. The bulls were housed in a thermally non-isolated stable and were kept in pens ( 8 animals per pen, each pen two animals per group) on slatted floor. The body weight was measured weekly with cattle weighing scales.

The experimental design included different $\mathrm{P}$ - and Zn-concentrations and phytase supplementation in the feed. The intended supply of $\mathrm{P}$ and $\mathrm{Zn}$ is related to the recommendations given by the GfE (1995). The feeding group P/Zn, P/Zn+PHY and $\mathrm{P} / \mathrm{Zn}+\mathrm{MIN}$ achieved $80 \%, \mathrm{P}+\mathrm{MIN} / \mathrm{Zn}$ achieved $100 \%$ of the intended P-concentration given by GfE (1995). Feeding group P/Zn, P+MIN/Zn and P/Zn+PHY got 80\%, P/Zn+MIN 100\% of 
the intended Zn-concentration given by GfE (1995). The diet of the experimental group $\mathrm{P} / \mathrm{Zn}+\mathrm{PHY}$ received additionally $0.1 \mathrm{~g}$ experimental Phytase per $\mathrm{kg} \mathrm{DM}$.

The experimental diets differed in the concentration of $\mathrm{P}, \mathrm{Zn}$ and phytase. The P/Zn-group received a basal diet with a P-concentration of approximately $2.4 \mathrm{~g} / \mathrm{kg}$ dry matter (DM) and a Zn-concentration of approximately $32 \mathrm{mg} / \mathrm{kg} \mathrm{DM}$ to cover approximately $80 \%$ of the present $\mathrm{P}$ and $\mathrm{Zn}$ recommendations (GfE, 1995) without phytase supplementation. The $\mathrm{P}+\mathrm{MIN} / \mathrm{Zn}$-group was fed the same diet added with P covering the P-demand of about 2.97 $\mathrm{g} / \mathrm{kg}$ DM. The P/Zn+PHY-group obtained the control diet added with an experimental phytase. According to the manufacturer's specifications the phytase had an activity of minimum 50.000 FYT/g. The quantity of the enzyme added to the concentrate amounted to $100 \mathrm{~g} / \mathrm{t} \mathrm{DM}$. The $\mathrm{P} / \mathrm{Zn}+\mathrm{MIN}$-group received the control diet with Zn-supplementation according to the recommendation (40 mg/kg DM) (GfE, 1995).

Table 1. Experimental design and realized concentrations

\begin{tabular}{|c|c|c|c|c|}
\hline & $\mathrm{P} / \mathrm{Zn}^{1}$ & $\mathrm{P}+\mathrm{MIN} / \mathrm{Zn}^{2}$ & $\mathrm{P} / \mathrm{Zn}+\mathrm{PHY} \mathrm{Y}^{3}$ & $\mathrm{P} / \mathrm{Zn}+\mathrm{MIN}^{4}$ \\
\hline \multicolumn{5}{|l|}{ Intended concentration } \\
\hline $\mathrm{P}(\mathrm{g} / \mathrm{kg} \mathrm{DM})$ & 2.4 & 2.97 & 2.3 & 2.4 \\
\hline $\mathrm{Zn}(\mathrm{mg} / \mathrm{kg} \mathrm{DM})$ & 32 & 32 & 32 & 40 \\
\hline Phytase (g/kg DM) & - & - & $0.1 *$ & - \\
\hline \multicolumn{5}{|c|}{ Intended supply related to the recommendations given by the GFE (1995) } \\
\hline $\mathrm{P}(\%)$ & 80 & 100 & 80 & 80 \\
\hline $\mathrm{Zn}(\%)$ & 80 & 80 & 80 & 100 \\
\hline \multicolumn{5}{|l|}{ Realised concentration } \\
\hline $\mathrm{P}(\mathrm{g} / \mathrm{kg} \mathrm{DM})$ & 2.41 & 2.99 & 2.48 & 2.41 \\
\hline $\mathrm{Zn}(\mathrm{mg} / \mathrm{kg} \mathrm{DM})$ & 33.2 & 33.6 & 34.0 & 38.8 \\
\hline Phytase (g/kg DM) & - & - & $0.1^{*}$ & - \\
\hline \multicolumn{5}{|c|}{ Realised percentage related to the recommendations given by the GFE (1995) } \\
\hline $\mathrm{P}(\%)$ & 79 & 100 & 86 & 82 \\
\hline $\mathrm{Zn}(\%)$ & 83 & 84 & 85 & 97 \\
\hline \multicolumn{5}{|c|}{ * The phytase had an activity of min. $50000 \mathrm{FYT} / \mathrm{g}$ according to the manufacturer's specifications. } \\
\hline \multicolumn{5}{|c|}{$\begin{array}{l}\text { FYT: one FYT is the amount of enzymes that liberates } 1 \mu \mathrm{mol} \text { of inorganic } \mathrm{P} \text { per minute from an excess of } \mathrm{Na} \\
\text { phytate at } \mathrm{pH} 5.5 \text { and } 37^{\circ} \mathrm{C}\end{array}$} \\
\hline \multicolumn{5}{|c|}{${ }^{1}$ diet with native $\mathrm{P}$ and $\mathrm{Zn}$ content } \\
\hline \multicolumn{5}{|c|}{${ }^{2}$ diet with supplemental mineral $\mathrm{P}$ and native $\mathrm{Zn}$ content } \\
\hline \multicolumn{5}{|c|}{${ }^{3}$ diet with native $\mathrm{P}$ and $\mathrm{Zn}$ content, added with phytase } \\
\hline${ }^{4}$ diet with native $\mathrm{P}$ cont & mental & $\mathrm{an}$ & & \\
\hline
\end{tabular}

The components of the concentrates used during the trial are shown in e.g. Table 2. Changes in mineral content were achieved by changes in the mineral premix in the concentrates. 
Table 2. Components, mean nutrient, fibre and energy of the concentrates and corn silage of the experimental diets

\begin{tabular}{|c|c|c|c|c|c|}
\hline & Corn silage & $\mathrm{C}-\mathrm{P} / \mathrm{Zn}^{1}$ & $\mathrm{C}-\mathrm{P}+\mathrm{MIN} / \mathrm{Zn}^{2}$ & $\mathrm{C}-\mathrm{P} / \mathrm{Zn}+\mathrm{PHY}^{3}$ & $\mathrm{C}-\mathrm{P} / \mathrm{Zn}+\mathrm{MIN}^{4}$ \\
\hline \multicolumn{6}{|c|}{ Components of the concentrates $(\mathrm{g} / \mathrm{kg})$} \\
\hline Wheat gluten & & 100 & 100 & 100 & 100 \\
\hline Corn & & 300 & 300 & 300 & 300 \\
\hline Dried sugar beet pulp & & 483.7 & 483.7 & 483.7 & 483.7 \\
\hline Calcium carbonate & & 36 & 16 & 36 & 36 \\
\hline Dicalcium phosphate & & - & 20 & - & - \\
\hline Soybean oil & & 12 & 12 & 12 & 12 \\
\hline Urea & & 30 & 30 & 30 & 30 \\
\hline Premix Control ${ }^{*}$ & & 8.3 & - & - & - \\
\hline Premix with $\mathrm{P}^{\dagger}$ & & - & 8.3 & - & - \\
\hline Premix with phytase ${ }^{\ddagger}$ & & - & - & 8.3 & - \\
\hline Premix with $\mathrm{Zn}^{\S}$ & & - & - & - & 8.3 \\
\hline $\begin{array}{l}\text { Mineral premix }{ }^{a} \\
\text { (without } \mathrm{P} \text { and } \mathrm{Zn} \text { ) }\end{array}$ & & 30 & 30 & 30 & 30 \\
\hline \multicolumn{6}{|c|}{ Nutrient, fibre and energy content of the concentrates and corn silage } \\
\hline Organic matter (g/kg DM) & 961 & 949 & 950 & 949 & 949 \\
\hline Crude ash (g/kg DM) & 39 & 51 & 50 & 51 & 51 \\
\hline Crude protein $(\mathrm{g} / \mathrm{kg} \mathrm{DM})$ & 82 & 118 & 115 & 119 & 117 \\
\hline Ether extract (g/kg DM) & 38 & 33 & 34 & 33 & 34 \\
\hline Crude fibre (g/kg DM) & 184 & 166 & 168 & 166 & 167 \\
\hline $\mathrm{ADF}(\mathrm{g} / \mathrm{kg} \mathrm{DM})$ & 208 & 190 & 192 & 190 & 191 \\
\hline $\mathrm{NDF}(\mathrm{g} / \mathrm{kg} \mathrm{DM})$ & 403 & 372 & 374 & 371 & 372 \\
\hline $\mathrm{P}(\mathrm{g} / \mathrm{kg} \mathrm{DM})$ & 2.33 & 2.85 & 5.59 & 2.93 & 2.76 \\
\hline $\mathrm{Zn}(\mathrm{g} / \mathrm{kg} \mathrm{DM})$ & 0.02 & 0.13 & 0.14 & 0.14 & 0.18 \\
\hline IP-6 (g/kg DM $)^{5}$ & \# & 0.67 & 0.47 & 0.67 & 0.68 \\
\hline IP-5 (g/kg DM $)^{5}$ & \# & 0.02 & 0.05 & 0.03 & 0.04 \\
\hline IP- $1 / 2 / 3 / 4(\mathrm{~g} / \mathrm{kg} \mathrm{DM})^{5}$ & $\#$ & \# & \# & \# & $\#$ \\
\hline $\mathrm{ME}(\mathrm{MJ} / \mathrm{kg} \mathrm{DM})$ & 10.7 & 11.9 & 11.9 & 11.9 & 11.9 \\
\hline
\end{tabular}




\begin{tabular}{|c|}
\hline${ }^{1}$ concentrate with native $\mathrm{P}$ and $\mathrm{Zn}$ content \\
\hline${ }^{2}$ concentrate with supplemental mineral $\mathrm{P}$ and native $\mathrm{Zn}$ content \\
\hline${ }^{3}$ concentrate with native $\mathrm{P}$ and $\mathrm{Zn}$ content, added with phytase \\
\hline${ }^{4}$ concentrate with native $\mathrm{P}$ content and supplemental mineral $\mathrm{Zn}$ \\
\hline${ }^{5}$ Inositol Phosphate \\
\hline${ }^{* / \uparrow} 98.76 \%$ Corn and $1.24 \%$ Zinc sulphate monohydrate (35\% Zinc in Zinc sulphate monohydrate) \\
\hline $\begin{array}{l}93.97 \% \text { Corn, } 1.23 \% \text { Zinc sulphate monohydrate and } 4.8 \% \text {, Experimental phytase (phytase activity } \\
\text { amounted to } 50000 \mathrm{FYT} / \mathrm{g} \text { ) }\end{array}$ \\
\hline $\begin{array}{l}{ }^{\S} 97.6 \% \text { Corn and } 2.4 \% \text { Zinc sulphate monohydrate } \\
\text { \# } \text { out of detection limit }\end{array}$ \\
\hline $\begin{array}{l}{ }^{\mathrm{a}} \text { Composition (per kg): } 560.000 \mathrm{IU} \text { vitamin A (E672), } 70.000 \mathrm{IU} \text { vitamin D3 (E671), } 1.050 \mathrm{mg} \text { vitamin E } \\
\text { (alpha tocopherolacetat), } 3.000 \mathrm{mg} \text { manganese (manganese (II) sulphate, monohydrate E5, } 700 \mathrm{mg} \\
\text { copper, } 50 \mathrm{mg} \text { iodine (calcium jodate, water-free E2), } 25 \mathrm{mg} \text { cobalt (cobalt sulphate, monohydrate, E3), } \\
30 \mathrm{mg} \text { selenium (sodium selenate E8) }\end{array}$ \\
\hline
\end{tabular}

The animals were fed with restricted amounts of concentrate $(2 \mathrm{~kg} / \mathrm{d})$ and corn silage for $a d$ libitum intake.

The concentrate was provided via feeding stations (Type AWS HF 2ST, manufacturer: Insentec, Marknesse, The Netherlands). Water was available for ad libitum intake during the whole experiment. Because corn silage and concentrates were fed separately the added phytase was not exposed to moisture and was therefore assumed to be inactive prior to feeding.

The diets were intended to cover the energy and protein requirements according to the recommendations of the Society of Nutrition Physiology (GfE 1995).

\subsection{Measurements and Sampling Procedure}

Individual silage and water intake were recorded continuously by an automatic feeding system (RIC, manufacturer Insentec B.V., Marknesse, The Netherlands). The body weight was measured weekly with cattle weighing scales. During the experiment, representative samples of the diets were collected regularly. Silage and concentrate samples were collected twice a week and weekly, respectively. After collecting, the samples were stored at $-18^{\circ} \mathrm{C}$ and pooled over a 4 weeks period.

Additionally, once during the experiment, samples of faeces were taken from every fourth bull of every treatment group for $\mathrm{P}-, \mathrm{Zn}$ - and acid insoluble ash-analysis.

The bulls were slaughtered at an average live weight of $578 \mathrm{~kg}$ at the slaughtering house of the Institute of Animal Nutrition, Friedrich-Loeffler-Institute, FLI, Braunschweig. At the day of slaughter samples of Os metacarpale, liver and testes were taken and stored frozen at $-20^{\circ} \mathrm{C}$ until further analysis.

\subsection{Analyses}

Feedstuff samples were dried at $60^{\circ} \mathrm{C}$ for 72 hours and ground to pass a 1-mm screen. The 
samples of Os metacarpale, testes and liver were freeze dried for the determination of $\mathrm{P}$ and $\mathrm{Zn}$. After freeze drying, the samples were ground in mortars and after that passed through a spiral screw mincer.

Samples of feedstuff and faeces were analyzed according to the methods of the Verband Deutscher Landwirtschaftlicher Untersuchungs- und Forschungsanstalten (VDLUFA 1997). Analysis of acid and neutral detergent fibre (ADF resp. NDF) was conducted following methods of VDLUFA (1997). P and $\mathrm{Zn}$ in feedstuff, bones, testes liver and faeces were analyzed by an optical emissions spectrometer with inductive coupled plasma (ICP-OES) according to VDLUFA (1997).

The digestibility of $\mathrm{Zn}$ and $\mathrm{P}$ was estimated by acid insoluble ash (AIA) as marker (Sunvold \& Cochran, 1991). AIA in feed and faeces was analyzed with an adapted 4N HCl-method based on the method described by Wünsche et al (1984) and Mccarthy et al. (1974). A total of 2 to 5 $\mathrm{g}$ of freeze dried faeces or feed were ashed. The ignition of the samples lasted 5 hours at a temperature of $550^{\circ} \mathrm{C}$. The ashes were boiled for 15 minutes with $4 \mathrm{~N} \mathrm{HCl}$ and the residues were filtered through an ashless filter paper. After drying the filters with the residues, they were ashed again to obtain the amount of AIA. Inositol-P was analysed in all feedstuff samples using high-performance ion chromatography according to the method of Brejnholt et al. (2011).

\subsection{Calculations}

The apparent total tract digestibility (AD) of $\mathrm{P}$ and $\mathrm{Zn}$ was estimated by acid insoluble ash as a marker occurring naturally in the diet as follows:

$\mathrm{AD}[\%]=\left(\left[\left(\mathrm{M}_{\text {diet }} / \mathrm{AIA}_{\text {diet }}\right)-\left(\mathrm{M}_{\text {faeces }} / \mathrm{AIA}_{\text {faeces }}\right)\right] / \mathrm{M}_{\text {diet }} / \mathrm{AIA}_{\text {diet }}\right) * 100$,

where $\mathrm{M}_{\text {diet }}$ is the mineral content $(\mathrm{P}, \mathrm{Zn})$ in $\mathrm{g} / \mathrm{kg} \mathrm{DM}$ and $\mathrm{AIA} \mathrm{A}_{\text {diet }}$ is the AIA content in $\mathrm{g} / \mathrm{kg}$ $\mathrm{DM}$ in the feed. $\mathrm{M}_{\text {faeces }}$ is the mineral content $(\mathrm{P}, \mathrm{Zn})$ in $\mathrm{g} / \mathrm{kg} \mathrm{DM}$ and $\mathrm{AIA}_{\text {faeces }}$ the AIA content $(\mathrm{g} / \mathrm{kg} \mathrm{DM})$ in faeces.

The energy content of the diets was calculated based on table values given by the DLG (1997).

The phytase activity for the corn silage is calculated according to tabulated values of Eeckhout and De Paepe (1994). This results in a phytase activity for corn silage of 12 FYT/kg DM.

Empty Body weight is defined as the body weight without the content of the rumen, intestine, gall and urinary bladder. Dressing percentage was calculated as quotient of warm carcass weight and body weight.

\subsection{Statistical Analysis}

The statistical analysis was carried out with the SAS-software package Version 9.1.3 using the MIXED-procedure (SAS Institute, Cary, NC, USA 2004).

Treatment group was assumed to be the fixed effect. The fact that each bull was used for frequent measurements was considered using a "REPEATED" statement for the individual animal effect. The "PDIFF" option was used to determine significant effects between the least square means and "TUKEY-KRAMER" test was applied for post-hoc analysis. The results of the trial are presented in form of least square means (LS means) and standard error 
$(\mathrm{SE})$ of the mean. Effects are considered as significant with a $\mathrm{p}<0.05$.

\section{Results}

\subsection{Chemical Composition of the Feedstuffs}

The chemical composition of the concentrates is shown in e.g. Table 2. As intended the P and $\mathrm{Zn}$-concentration of the groups manifested variations.

The proportion of phytate-P (IP-6/5/4/3/2/1) of the total $\mathrm{P}$ of the concentrates amounted to $24 \%$, $24 \%$ and $26 \%$ phytate-P in the P/Zn-, P/Zn+PHY- and P/Zn+MIN-group. Because of the supplementation of inorganic $\mathrm{P}$ in the $\mathrm{P}+\mathrm{MIN} / \mathrm{Zn}$-group, the percentage of phytate- $\mathrm{P}$ was lower and amounted to $9 \%$.

The concentrated feed of group $\mathrm{P} / \mathrm{Zn}, \mathrm{P}+\mathrm{MIN} / \mathrm{Zn}$ and $\mathrm{P} / \mathrm{Zn}+\mathrm{MIN}$ showed no detectable phytase activity, while the feed of the P/Zn+PHY group showed a phytase activity of $5859 \pm 15$ $\mathrm{FYT} / \mathrm{kg}$.

\subsection{Performance}

Corn silage intake amounted on average to $6.65 \mathrm{~kg} \mathrm{DM} / \mathrm{d}$. No differences were observed in corn silage intake across the treatments. The mean concentrate intake was $1.75 \pm 0.03 \mathrm{~kg} \mathrm{DM} / \mathrm{d}$ and ranged from 1.72 to $1.78 \mathrm{~kg} \mathrm{DM} / \mathrm{d}$ e.g. Table 3 . As intended the mean P-intake was significantly higher in the $\mathrm{P}+\mathrm{MIN} / \mathrm{Zn}$-group with $26.2 \mathrm{~g} / \mathrm{d}$ and the mean $\mathrm{Zn}$-intake was significantly higher in the $\mathrm{P} / \mathrm{Zn}+\mathrm{MIN}$-group with $0.32 \mathrm{~g} / \mathrm{d}$, as compared to the other groups.

Table 3. Mean feed and nutrient intakes during the experimental period (LS-means, SE)

\begin{tabular}{|l|c|c|c|c|c|c|}
\hline & $\mathrm{P} / \mathrm{Zn}^{1}$ & $\mathrm{P}+\mathrm{MIN} / \mathrm{Zn}^{2}$ & $\mathrm{P} / \mathrm{Zn}+\mathrm{PHY} \mathrm{Y}^{3}$ & $\mathrm{P} / \mathrm{Zn}+\mathrm{MIN}^{4}$ & $* \mathrm{SE}$ & $P$-value \\
\hline Animals/group & 12 & 12 & 12 & 12 & & \\
\hline DM intake (kg/d) & 8.1 & 8.8 & 8.2 & 8.3 & 0.27 & 0.072 \\
\hline $\begin{array}{l}\text { Corn silage } \\
\text { (kg DM/d) }\end{array}$ & 6.4 & 7.1 & 6.5 & 6.6 & 0.32 & 0.442 \\
\hline $\begin{array}{l}\text { Concentrate } \\
\text { (kg DM/d) }\end{array}$ & 1.74 & 1.74 & 1.78 & 1.72 & 0.02 & 0.060 \\
\hline Crude protein (kg/d) & 0.95 & 1.01 & 0.98 & 0.97 & 0.03 & 0.421 \\
\hline Ether extract (kg/d) & 0.27 & 0.29 & 0.28 & 0.28 & 0.01 & 0.449 \\
\hline ADF (kg/d) & 1.53 & 1.68 & 1.57 & 1.58 & 0.07 & 0.432 \\
\hline NDF (kg/d) & 3.00 & 3.28 & 3.05 & 3.08 & 0.13 & 0.423 \\
\hline P (g/d) & $19.6^{\mathrm{b}}$ & $26.2^{\mathrm{a}}$ & $20.3^{\mathrm{b}}$ & $20.1^{\mathrm{b}}$ & 0.65 & $<0.001$ \\
\hline Zn (mg/d) & $270^{\mathrm{a}}$ & $294^{\mathrm{b}}$ & $280^{\mathrm{ab}}$ & $321^{\mathrm{c}}$ & 6.5 & $<0.001$ \\
\hline \\
ME intake (MJ/d)
\end{tabular}




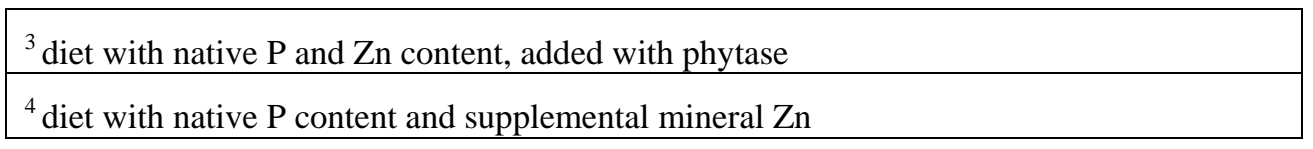

The average live weight gain did not differ between the treatments e.g. Table 4 . The average live weight gain during the whole experiment was $1360 \pm 84 \mathrm{~g} / \mathrm{d}$. In the $\mathrm{P} / \mathrm{Zn}$ - and $\mathrm{P} / \mathrm{Zn}+\mathrm{PHY}$-group the daily live weight gain was numerically higher at the beginning of the experiment, while the bulls of the P+MIN/Zn- and P/Zn+MIN-group had a numerically higher daily live weight gain from day 101 until the end of the experiment. The average live weight gain of all groups was for the period from day 0-100 $1381 \pm 64 \mathrm{~g} / \mathrm{d}$. It was $1345 \pm 107 \mathrm{~g} / \mathrm{d}$ for day 101 to the end of trial. Mean feed per gain ratio ( $\mathrm{kg} \mathrm{DM} / \mathrm{kg} \mathrm{LWG)} \mathrm{was} 6.03 \pm 0.15 \mathrm{~kg} \mathrm{DM} / \mathrm{kg}$ LWG, until day 101 and $6.78 \pm 0.24 \mathrm{~kg}$ DM/kg LWG from day 101 until the end. For the whole period mean feed per gain was $6.30 \pm 0.19 \mathrm{~kg} \mathrm{DM} / \mathrm{kg}$ LWG. Overall means for energy intake per gain were $66 \pm 2 \mathrm{MJ} \mathrm{ME} / \mathrm{kg}$ LWG for day 1-100, 74 $\pm 3 \mathrm{MJ} \mathrm{ME} / \mathrm{kg}$ LWG for day 100-end and for the whole period $69 \pm 2 \mathrm{MJ}$ ME/kg LWG.

Table 4. Live weight gain (LWG) and feed efficiency subjected to the feeding groups $(n=12)$ (LS-means, SE)

\begin{tabular}{|c|c|c|c|c|c|c|}
\hline & $\mathrm{P} / \mathrm{Zn}^{1}$ & $\mathrm{P}+\mathrm{MIN} / \mathrm{Zn}^{2}$ & $\mathrm{P} / \mathrm{Zn}+\mathrm{PHY}^{3}$ & $\mathrm{P} / \mathrm{Zn}+\mathrm{MIN}^{4}$ & *SE & $P$-value \\
\hline Animals/group & 12 & 12 & 12 & 12 & & \\
\hline \multicolumn{7}{|c|}{ Daily live weight gain $(\mathrm{g} / \mathrm{d})$} \\
\hline day $1-100$ & 1455 & 1413 & 1321 & 1334 & 165 & 0.824 \\
\hline day 101-end & 1284 & 1474 & 1234 & 1387 & 154 & 0.417 \\
\hline Total period & 1379 & 1438 & 1275 & 1348 & 83 & 0.265 \\
\hline \multicolumn{7}{|c|}{ Feed per gain ( $\mathrm{kg} D M / \mathrm{kg} L W G$ ) } \\
\hline day $1-100$ & 5.87 & 5.93 & 6.20 & 6.11 & 0.5 & 0.914 \\
\hline day 101-end & 6.74 & 6.70 & 7.11 & 6.55 & 0.6 & 0.840 \\
\hline Total period & 6.14 & 6.25 & 6.57 & 6.23 & 0.3 & 0.611 \\
\hline \multicolumn{7}{|c|}{ Energy intake per gain (MJ ME/kg LWG) } \\
\hline day $1-100$ & 64.8 & 63.4 & 68.3 & 66.3 & 5.7 & 0.844 \\
\hline day 101-end & 74.4 & 71.7 & 78.3 & 71.2 & 6.9 & 0.713 \\
\hline Total period & 67.8 & 66.9 & 72.4 & 67.7 & 3.5 & 0.376 \\
\hline \multicolumn{7}{|l|}{ * Standard Error } \\
\hline \multicolumn{7}{|c|}{${ }^{1}$ diet with native $\mathrm{P}$ and $\mathrm{Zn}$ content } \\
\hline \multicolumn{7}{|c|}{${ }^{2}$ diet with supplemental mineral $\mathrm{P}$ and native $\mathrm{Zn}$ content } \\
\hline \multicolumn{7}{|c|}{${ }^{3}$ diet with native $\mathrm{P}$ and $\mathrm{Zn}$ content, added with phytase } \\
\hline
\end{tabular}

Twenty four out of the 48 bulls were slaughtered. Six bulls out of every feeding group were sampled. Mean body weight of the slaughtered bulls was of $581 \pm 8 \mathrm{~kg}$, while the dressing percentage amounted to $56 \pm 1 \%$. Considering the treatments, body weight, empty body weight, 
retroperitoneal fat and dressing did not show any significant differences e.g. Table 5.

Table 5. Body weights of the bulls at slaughter and carcass characteristics (n=6) (LS-means, $\mathrm{SE})$

\begin{tabular}{|c|c|c|c|c|c|c|}
\hline & $\mathrm{P} / \mathrm{Zn}^{1}$ & $\mathrm{P}+\mathrm{MIN} / \mathrm{Zn}^{2}$ & $\mathrm{P} / \mathrm{Zn}+\mathrm{PHY}^{3}$ & $\mathrm{P} / \mathrm{Zn}+\mathrm{MIN}^{4}$ & $* \mathrm{SE}$ & $P$-value \\
\hline Animals/group & 6 & 6 & 6 & 6 & & \\
\hline Body weight (kg) & 577 & 584 & 577 & 584 & 24 & 0.984 \\
\hline $\mathrm{EBW}^{\dagger}(\mathrm{kg})$ & 514 & 525 & 516 & 519 & 22 & 0.959 \\
\hline Fat of pelvic cavity and kidneys (g) & 2365 & 2052 & 2371 & 2087 & 238 & 0.391 \\
\hline Dressing $^{\ddagger}(\%)$ & 55.5 & 56.4 & 55.6 & 55.9 & 0.90 & 0.760 \\
\hline \multicolumn{7}{|l|}{ * Standard Error } \\
\hline \multicolumn{7}{|c|}{$\begin{array}{l}\text { Empty Body weight is defined as the body weight less the content of the rumen, intestine, gall and urinary } \\
\text { bladder }\end{array}$} \\
\hline \multicolumn{7}{|c|}{${ }^{\ddagger}$ Dressing is calculated as carcass weight as percentage of body weight at slaughter } \\
\hline \multicolumn{7}{|l|}{${ }^{1}$ diet with native $\mathrm{P}$ and $\mathrm{Zn}$ content } \\
\hline \multicolumn{7}{|c|}{${ }^{2}$ diet with supplemental mineral $\mathrm{P}$ and native $\mathrm{Zn}$ content } \\
\hline \multicolumn{7}{|c|}{${ }^{3}$ diet with native $\mathrm{P}$ and $\mathrm{Zn}$ content, added with phytase } \\
\hline${ }^{4}$ diet with native $\mathrm{P}$ content and sup & ental & eral Zn & & & & \\
\hline
\end{tabular}

The weight of the spleen tended to be lower in the P/Zn- and P/Zn+PHY-group than in the $\mathrm{P} / \mathrm{Zn}+\mathrm{MIN}$-group and the weight of the heart tended to be lower in the P/Zn+PHY- as compared to the P/Zn+MIN-group e.g. Table 6. The treatments had no influence on the weight of lung, liver, kidneys, testes, pancreas, prostate and thyroid gland.

Table 6. Weight of different organs at slaughter (g per $100 \mathrm{~kg} \mathrm{LWG)} \mathrm{depending} \mathrm{on} \mathrm{the} \mathrm{diet}$ $(n=6)(L S-m e a n s, S E)$

\begin{tabular}{|l|c|c|c|c|c|c|}
\hline & ${\mathrm{P} / \mathrm{Zn}^{1}}$ & $\mathrm{P}+\mathrm{MIN} / \mathrm{Zn}^{2}$ & $\mathrm{P} / \mathrm{Zn}+\mathrm{PHY}^{3}$ & $\mathrm{P} / \mathrm{Zn}+\mathrm{MIN}^{4}$ & ${ }^{*} \mathrm{SE}$ & $P$-value \\
\hline Animals/group & 6 & 6 & 6 & 6 & & \\
\hline Heart & 420 & 425 & 406 & 392 & 9 & 0.082 \\
\hline Liver & 1357 & 1360 & 1348 & 1314 & 30 & 0.689 \\
\hline Kidneys & 225 & 202 & 222 & 202 & 9 & 0.138 \\
\hline Testes & 174 & 169 & 176 & 175 & 10 & 0.950 \\
\hline Lung & 650 & 663 & 620 & 743 & 38 & 0.156 \\
\hline Spleen & 190 & 195 & 180 & 216 & 9 & 0.062 \\
\hline Pancreas & 55 & 70 & 74 & 73 & 7 & 0.228 \\
\hline Prostate & 59 & 70 & 58 & 70 & 10 & 0.746 \\
\hline Thyroidgland & 6 & 7 & 6 & 6 & 1 & 0.855 \\
\hline a, b Different letters in one row show significant differences (P<0.05) \\
\hline * Standard Error
\end{tabular}




\begin{tabular}{|l|}
\hline${ }^{1}$ diet with native $\mathrm{P}$ and $\mathrm{Zn}$ content \\
\hline${ }^{2}$ diet with supplemental mineral $\mathrm{P}$ and native $\mathrm{Zn}$ content \\
\hline${ }^{3}$ diet with native $\mathrm{P}$ and $\mathrm{Zn}$ content, added with phytase \\
\hline${ }^{4}$ diet with native $\mathrm{P}$ content and supplemental mineral $\mathrm{Zn}$ \\
\hline
\end{tabular}

\section{$3.3 P$ and $Z n$ in Faeces}

There were no significant differences between the treatments, but the P+MIN/Zn-group showed the numerically highest P-concentration e.g. Table 7.

All four groups together showed a mean P-concentration of faeces of $4.6 \pm 0.9 \mathrm{~g} / \mathrm{kg} \mathrm{DM}$. The averaged $\mathrm{Zn}$-concentration of the faeces samples was $102 \pm 8 \mathrm{mg} / \mathrm{kg} \mathrm{DM}$.

\section{4 $P$ and Zn-digestibility}

The digestibility of $\mathrm{P}$ and $\mathrm{Zn}$ showed no significant differences between the treatments e.g. Table 7. All four groups together showed a mean $\mathrm{P}$ digestibility of 48 percent and a mean $\mathrm{Zn}$ digestibility of 16.3 percent.

Table 7. P- and $\mathrm{Zn}$ - concentration in faeces (g/kg DM), excretion with faeces (g/d) and digestibility depending on the $\operatorname{diet}(\mathrm{n}=3)$ (LS means, SE)

\begin{tabular}{|c|c|c|c|c|c|c|}
\hline & $\mathrm{P} / \mathrm{Zn}^{1}$ & $\mathrm{P}+\mathrm{MIN} / \mathrm{Zn}^{2}$ & $\mathrm{P} / \mathrm{Zn}+\mathrm{PHY}$ & $\mathrm{P} / \mathrm{Zn}+\mathrm{MIN}^{4}$ & *SE & $P$-value \\
\hline \multicolumn{7}{|c|}{ Concentration ( $\mathrm{g} / \mathrm{kg}$ DM) } \\
\hline $\mathrm{P}$ & 4.1 & 5.6 & 3.9 & 4.5 & 0.60 & 0.218 \\
\hline $\mathrm{Zn}$ & 0.1 & 0.1 & 0.1 & 0.1 & 0.01 & 0.452 \\
\hline \multicolumn{7}{|c|}{ Excretion $(g / d)$} \\
\hline $\mathrm{P}$ & 9.0 & 11.9 & 10.6 & 10.2 & 1.77 & 0.718 \\
\hline $\mathrm{Zn}$ & 0.04 & 0.04 & 0.04 & 0.08 & 0.04 & 0.786 \\
\hline \multicolumn{7}{|c|}{ Digestibility (\%) } \\
\hline $\mathrm{P}$ & 49.0 & 47.7 & 48.9 & 50.2 & 6 & 0.994 \\
\hline $\mathrm{Zn}$ & 14.1 & 12.3 & 13.9 & 24.8 & 13 & 0.889 \\
\hline \multicolumn{7}{|c|}{ * Standard Error } \\
\hline \multicolumn{7}{|c|}{${ }^{1}$ diet with native $\mathrm{P}$ and $\mathrm{Zn}$ content } \\
\hline \multicolumn{7}{|c|}{${ }^{2}$ diet with supplemental mineral $\mathrm{P}$ and native $\mathrm{Zn}$ content } \\
\hline \multicolumn{7}{|c|}{${ }^{3}$ diet with native $\mathrm{P}$ and $\mathrm{Zn}$ content, added with phytase } \\
\hline${ }^{4}$ diet & . & $\mathrm{col}$ & prlamon & neral Zn & & \\
\hline
\end{tabular}

\subsection{Analysis of Organs}

There were no differences in $\mathrm{P}$ - and $\mathrm{Zn}$-concentration in liver and testes e.g. Table 8. In $O s$ metacarpale the P-concentration tended to be influenced by the treatments $(P=0.062)$. The animals of the $\mathrm{P}+\mathrm{MIN} / \mathrm{Zn}$-group showed the highest $\mathrm{P}$-concentration in bones $(95.9 \mathrm{~g} / \mathrm{kg} \mathrm{DM})$ while the P/Zn+MIN-group had the numerically lowest value $(90.0 \mathrm{~g} / \mathrm{kg} \mathrm{DM})$ e.g. Table 8 . 
Table 8. P- and Zn-concentration of liver, testes and Os metacarpale ( $\mathrm{n}=6)$ (LS-means and SE)

\begin{tabular}{|c|c|c|c|c|c|c|}
\hline & $\mathrm{P} / \mathrm{Zn}^{1}$ & $\mathrm{P}+\mathrm{MIN} / \mathrm{Zn}^{2}$ & $\mathrm{P} / \mathrm{Zn}+\mathrm{PHY}^{3}$ & $\mathrm{P} / \mathrm{Zn}+\mathrm{MIN}^{4}$ & *SE & $P$-value \\
\hline Animals/group & 6 & 6 & 6 & 6 & & \\
\hline \multicolumn{7}{|l|}{ Liver } \\
\hline $\mathrm{P}(\mathrm{g} / \mathrm{kg} \mathrm{DM})$ & 10.7 & 10.5 & 10.3 & 10.1 & 0.3 & 0.181 \\
\hline $\mathrm{Zn}(\mathrm{mg} / \mathrm{kg} \mathrm{DM})$ & 104 & 97 & 103 & 93 & 6 & 0.247 \\
\hline \multicolumn{7}{|l|}{ Testes } \\
\hline $\mathrm{P}(\mathrm{g} / \mathrm{kg} \mathrm{DM})$ & 6.1 & 5.5 & 6.2 & 5.4 & 0.9 & 0.756 \\
\hline $\mathrm{Zn}(\mathrm{mg} / \mathrm{kg} \mathrm{DM})$ & 41.5 & 36.7 & 39.9 & 35.4 & 5 & 0.641 \\
\hline \multicolumn{7}{|l|}{ Os metacarpale } \\
\hline $\mathrm{P}(\mathrm{g} / \mathrm{kg} \mathrm{DM})$ & 92.6 & 95.9 & 95.1 & 90.0 & 2 & 0.062 \\
\hline $\mathrm{Zn}(\mathrm{mg} / \mathrm{kg} \mathrm{DM})$ & 57.9 & 60.4 & 57.3 & 58.0 & 3 & 0.657 \\
\hline \multicolumn{7}{|l|}{${ }^{*}$ Standard Error } \\
\hline \multicolumn{7}{|c|}{${ }^{1}$ diet with native $\mathrm{P}$ and $\mathrm{Zn}$ content } \\
\hline \multicolumn{7}{|c|}{${ }^{2}$ diet with supplemental mineral $\mathrm{P}$ and native $\mathrm{Zn}$ content } \\
\hline${ }^{3}$ diet with native $\mathrm{F}$ & nd Zn & intent, add & ith phytase & & & \\
\hline
\end{tabular}

\section{Discussion}

The P- and Zn-reduced diet should be compared to $\mathrm{P}$ or $\mathrm{Zn}$ supplemented diets and a $\mathrm{P}$ - and $\mathrm{Zn}$-reduced diet added with phytase. Feeding these four different diets, it should be possible to figure out if the supplemented enzyme is able to compensate the deficiency by splitting up more indigestible $\mathrm{P}$ - and $\mathrm{Zn}$-complexes than the rumen microbes do. The intended $\mathrm{P}$-concentrations in the diets of group $\mathrm{P} / \mathrm{Zn}, \mathrm{P}+\mathrm{MIN} / \mathrm{Zn}, \mathrm{P} / \mathrm{Zn}+\mathrm{PHY}$ and $\mathrm{P} / \mathrm{Zn}+\mathrm{MIN}$ as well as the desired difference of $20 \%$ between the groups with or without P- and $\mathrm{Zn}$-supplementation were almost achieved. The feed ingredients including corn silage, corn, wheat gluten and dried sugar beet pulp contributed to the comparatively low dietary P-concentration. The $\mathrm{P}$-concentration of the corn silage was on average $2.33 \mathrm{~g} / \mathrm{kg}$ DM and the mean P-concentration of the unsupplemented concentrates was $2.85 \mathrm{~g} / \mathrm{kg} \mathrm{DM}$. With 24 to $26 \%$ phytate P (sum of InsP-6/5/4/3/2/1) of total $\mathrm{P}$ of concentrates of the unsupplemented groups, the current study supports the data of Maenz (2001). Maenz (2001) investigated the occurrence of phytic acid in plants and found that cereals and grain legumes that are commonly used as feed ingredients all have similar phytate levels. The content of phytate $\mathrm{P}$ in the concentrate of the $\mathrm{P}$-supplemented group was only $9 \%$. This can be explained with the supplementation of inorganic $\mathrm{P}$ in the $\mathrm{P}+\mathrm{MIN} / \mathrm{Zn}$-group, while the $\mathrm{P}$ content of the other groups is native.

The requirement of $\mathrm{Zn}$ is met when the diet contains $40 \mathrm{mg} \mathrm{Zn} / \mathrm{kg}$ dry matter intake (DMI) for bulls (GfE, 1995). The P- and Zn-reduction of group P/Zn+PHY to 86 respectively $85 \%$ related to the recommendations given by the GfE (1995) should be compensated by the effect of the supplemented exogenous phytase. Brask-Pedersen et al. (2011) and Garikipati and Kincaid 
(2004) found, that exogenous phytase can influence the availability of $\mathrm{P}$ positively. As $\mathrm{Zn}$ is probably the most vulnerable mineral to phytate complexation (Kornegay, 2001) it seems possible that exogenous phytase could decrease $\mathrm{Zn}$-excretion with faeces, too.

But in the actual study, there are no differences visible between the $\mathrm{P} / \mathrm{Zn}$ - and $\mathrm{P} / \mathrm{Zn}+\mathrm{PHY}$-group. Phytase showed neither an effect on the $\mathrm{P}$ and $\mathrm{Zn}$-excretion with faeces nor on the $\mathrm{P}$ and $\mathrm{Zn}$ digestibility of the animals.

Geisert et al. (2010) investigated the relationship between $\mathrm{P}$ requirement and excretion of finishing beef cattle fed different concentrations of P. Geisert et al. (2010) did not find differences in the DMI depending on P-intake. In contrast, in the present study there was a tendency towards a higher feed intake of the $\mathrm{P}+\mathrm{MIN} / \mathrm{Zn}$ group $(P=0.072)$. The DMI of this group was 0.5 to $0.7 \mathrm{~kg}$ per day higher compared with the other groups. Like in the study of Geisert et al. (2010) there were no differences in DMI depending on P-intake. The observation that feed intake was not affected by Zn-treatment is in agreement with Khan (1978) and Mandal et al. (2007), where feed intake of growing calves and bulls was unaffected by an increase of dietary Zn-concentration of $2.5 \mathrm{mg} Z \mathrm{Zn} / \mathrm{kg}$ DM. Supplementations of Zn methionine to a diet containing more than $25 \mathrm{mg} \mathrm{Zn/kg} \mathrm{DM} \mathrm{did} \mathrm{not} \mathrm{affect} \mathrm{feed} \mathrm{intake} \mathrm{in} \mathrm{ewes} \mathrm{(Salama}$ Ahmed, 2003), goats (Puchala et al., 1999), growing lambs (Droke et al., 1998), beef steers (Duff et al., 2000) and bulls (Mandal et al., 2007). Mandal et al. (2007) investigated diets for growing bulls with a Zn-concentration of 32 and $35 \mathrm{mg} \mathrm{Zn/kg} \mathrm{DM,} \mathrm{respectively.} \mathrm{That} \mathrm{complies}$ with $80 \%$ and $87.5 \%$ of the recommendations given by the GfE (1995). The different $\mathrm{Zn}$-concentrations did not affect the intake and balance of minerals like $\mathrm{Ca}$ and $\mathrm{P}$ in bulls. In accordance with Mandal et al. (2007) in the present study no effect of Zn-treatment on P-intake, $\mathrm{P}$-excretion and P-digestibility was detected, while $\mathrm{Zn}$-supplementation to feed results as desired in higher Zn-intake in group P/Zn+MIN. Contrary to Mandal et al. (2007), the current study showed no influence of Zn-supplementation on Zn-excretion with faeces and the Zn-digestibility.

Fattening bulls excrete the main part with faeces and only $1 \%$ of total P- excretion with urine (Klosch et al., 1994; Vitti et al., 2000). Klosch et al. (1994) investigated that the faecal P-excretion of fattening bulls is between 0.71 and $1.10 \mathrm{~g} / \mathrm{kg}$ DMI. Calculating the faecal P-excretion of the animals during the current study considering these assumptions, the P-excretion should amount from 5.75 to $9.7 \mathrm{~g} / \mathrm{d}$. In the actual study the analyzed P-excretion with faeces ranges from $9.0 \mathrm{~g}$ to $11.9 \mathrm{~g} / \mathrm{d}$. Consequential the faecal P-excretion was between 1.0 and $1.6 \mathrm{~g} / \mathrm{kg}$ DMI. While Geisert et al. (2010) observed a significant effect of P-intake on the faecal P-excretion in a study with steers, the P+MIN/Zn-group of the actual study showed a tendency towards a higher $\mathrm{P}$-excretion compared with the other groups $(P=0.085)$. Both results indicate that faecal losses were related to P-intake. This was also confirmed by studies with dairy cattle (Braithwaite, 1985; Khorasani et al., 1997; Scott \& Buchan, 1985; Ternouth, 1989; Valk et al., 2002).

To get an impression of the $\mathrm{P}$ retention in body, the $\mathrm{P}$-balance was calculated. The P-excretion with urine was assumed to be $1 \%$ of total P-excretion and consequently amounts to $0.1 \mathrm{~g} / \mathrm{d}$. Taking the P-excretion with faeces e.g. Table 7 and the calculated P-excretion with urine into 
account, P-balances are as follows: 10.4, 14.2, 9.6 and $9.8 \mathrm{~g} / \mathrm{d}$ for groups $\mathrm{P} / \mathrm{Zn}, \mathrm{P}+\mathrm{MIN} / \mathrm{Zn}$, $\mathrm{P} / \mathrm{Zn}+\mathrm{PHY}$ and P/Zn+MIN. Winter et al. (2013) investigated the P-balance of lactating cows fed comparable diets. The study resulted in P-balances between 16.2 and $26.4 \mathrm{~g} / \mathrm{d}$. The difference between the studies can be explained with the gender and the age of the animals.

Compared to the P-excretion, the Zn-excretion showed a similar pattern. While Mandal et al. (2006) found significantly higher Zn-excretion with faeces and urine of Zn-supplemented groups, in the actual experiment with fattening bulls, these results could not be confirmed.

The skeleton is the main P-storage (Fernandez, 1995; Pfeffer et al., 2005). 80\% of whole body $\mathrm{P}$ is stored in bones, while the remaining part is contained in tissues and fluids (Kirchgessner et al., 1994). Taking this fact and the P-balance in the actual study into account, a quantity of 8.3, 11.4, 7.7 and $7.8 \mathrm{~g} \mathrm{P} / \mathrm{d}$ is stored in the bones (groups $\mathrm{P} / \mathrm{Zn}, \mathrm{P}+\mathrm{MIN} / \mathrm{Zn}, \mathrm{P} / \mathrm{Zn}+\mathrm{PHY}$ and $\mathrm{P} / \mathrm{Zn}+\mathrm{MIN})$. The P-concentration of bones is different, depending on the particular type of bone. Results of investigations by Williams et al. (1991) indicate that chemical and physical properties of bovine bones are sensitive to dietary P. Erickson et al. (2002) studied the effects of dietary P-concentration on quantity and route of P-excretion and P-concentration in the bones of cattle feed finishing diets over 180 days. They concluded like Shupe et al. (1988), Ternouth (1990) and Geisert et al. (2010) that the metacarpal bone of cattle could be an indicator of mineral status. The ash of Os metacarpale showed an average P content of $17.3 \%$. In the actual study, the phytase as well as the P-supplementation to a diet low in $\mathrm{P}$ tended to increase the $\mathrm{P}$-concentration in Os metacarpale $(P=0.062)$. Therefore, it can be ascertained that there seems to be a potential of the tested phytase to replace mineral $\mathrm{P}$-supplementation under $\mathrm{P}$ deficient conditions.

An interesting aspect of the present study is the liver with its $\mathrm{Zn}$ binding protein, metallothioneins (MTs). MTs have the ability of releasing Zn, when necessary (Tapiero \& Tew, 2003). For this reason the question arises if the $\mathrm{Zn}$-concentration in the liver increases linear to the $\mathrm{Zn}$-supplementation of the diet. Cao et al. (2000) analyzed the Zn-concentration of the liver of growing lambs depending on the dietary $\mathrm{Zn}$-intake and ascertained that the $\mathrm{Zn}$-concentration of the liver increased linearly with the Zn-concentration of the diet. Wright and Spears (2004) studied the effect of different $\mathrm{Zn}$ sources and different amounts of supplementation on the $\mathrm{Zn}$-concentration in the liver and bones of calves. They found that the $\mathrm{Zn}$-concentration in the liver and bones rose linearly with the $\mathrm{Zn}$-intake. In contrast to these results, no relation between the dietary $\mathrm{Zn}$-intake and $\mathrm{Zn}$-concentration in the liver and bones were observed in the present study. An explanation for the differences between calves and fattening bulls could be a more effective homeostatic control mechanism of older animals which is responsible for the regulation of the $\mathrm{Zn}$ content of liver tissue (Kincaid et al., 1997).

In the actual study, the $\mathrm{P}$ - and $\mathrm{Zn}$-concentration of the testes was not influenced by the dietary treatment. These results were in line with the studies of Wright et al. (2004) and Cao et al. (2000) who found similar effects. There was no effect of dietary treatment on the weight of testes, too. Foote et al. (1977) observed a positive relation between the number of sperms and the size of scrotum. Amstutz (1979) detected a positive relation between the size of scrotum and the motility of sperms in ejaculate of bulls. Furthermore density of ejaculate is sensitive to 
external parameters like genetic and feed. In addition there is evidence that a $\mathrm{Zn}$ supplementation could have a positive influence on the fertility of bulls.

The logical effect of this study is that the microbial phytase of the rumen is sufficient enough to make the indigestible phytate-P and the hardly digestible $\mathrm{Zn}$ digestible for ruminants.

\section{Conclusions}

In the present study a supplementation of phytase has no influence on the feed intake, live weight gain, feed efficiency, slaughter characteristics and $\mathrm{P}$ and $\mathrm{Zn}$ digestibility. Only the $\mathrm{P}$-concentration of Os metacarpale tended to be increased for animals fed a $\mathrm{P}$ deficient diet supplemented with phytase. Under the conditions of the present study the microbial phytase in the rumen appears to be sufficient to make the phytate bound $\mathrm{P}$ and the hardly digestible $\mathrm{Zn}$ available for the animals.

\section{Acknowledgements}

The authors would like to thank the DSM Nutritional Products Ltd for financial support. Furthermore, the assistance of the co-workers of the Institute of Animal Nutrition, Friedrich-Loeffler-Institute (FLI) and the Experimental Station of the Institute of Animal Nutrition in Braunschweig, Germany in performing the experiment and analysis is gratefully acknowledged.

\section{References}

Adeola, O., Lawrence, B. V., Sutton, A. L., \& Cline, T. R. (1995). Phytase-Induced Changes in Mineral Utilization in Zinc-Supplemented Diets for Pigs. Journal of Animal Science. 73(11). 3384-3391.

Amstutz, H. E. (1979). Bull Infertility. Modern Veterinary Practice. 60(1). 52-53.

Barney, G. H., Orgebinc. Mc, \& Macapinl. Mp. (1968). Genesis of Esophageal Parakeratosis and Histologic Changes in Testes of Zinc-Deficient Rat and Their Reversal by Zinc Repletion. Journal of Nutrition. 95(4), 526.

Braithwaite, G. D. (1985). Endogenous Fecal Loss of Phosphorus in Growing Lambs and the Calculation of Phosphorus Requirements. Journal of Agricultural Science. 105(Aug). 67-72. http://dx.doi.org/10.1017/S0021859600055726

Brask-Pedersen, D. N., Glitso, L. V., Skov, L. K., Lund, P., \& Sehested, J. (2011). Effect of exogenous phytase on feed inositol phosphate hydrolysis in an in vitro rumen fluid buffer system. Journal of Dairy Science. 94(2), 951-959. http://dx.doi.org/10.3168/jds.2010-3504

Brejnholt, S. M., Dionisio, G., Glitsoe, V., Skov, L. K., \& Brinch-Pedersen, H. (2011). The degradation of phytate by microbial and wheat phytases is dependent on the phytate matrix and the phytase origin. Journal of the Science of Food and Agriculture. 91(8), 1398-1405. http://dx.doi.org/10.1002/jsfa.4324

Call, J. W., Butcher, J. E., Shupe, J. L., Lamb, R. C., Boman, R. L., \& Olson, A. E. (1987). Clinical Effects of Low Dietary Phosphorus Concentrations in Feed Given to Lactating 
Dairy-Cows. American Journal of Veterinary Research. 48(1), 133-136.

Cao, J., Henry, P. R., Guo, R., Holwerda, R. K., Toth, J. P., Littell, R. C., Miles, R. D., \& Ammerman, C. B. (2000). Chemical characteristics and relative bioavailability of supplemental organic zinc sources for poultry and ruminants. Journal of Animal Science. 78(8), 2039-2054.

Clark, W. D., Wohlt, J. E., Gilbreath, R. L., \& Zajac, P. K. (1986). Phytate Phosphorus Intake and Disappearance in the Gastrointestinal-Tract of High Producing Dairy-Cows. Journal of Dairy Science. 69(12), 3151-3155. http://dx.doi.org/10.3168/jds.S0022-0302(86)80780-9

DLG, D. U. H. (1997). DLG Futterwerttabellen Wiederkäuer (Feed value tables for ruminants) (Vol. 7th), Frankfurt am Main, Germany: DLG-Verlag.

Droke, E. A., Gengelbach, G. P., \& Spears, J. W. (1998). Influence of level and source (inorganic vs organic) of zinc supplementation on immune function in growing lambs. Asian-Australasian Journal of Animal Sciences. 11(2), 139-144.

Duff, G. C., Walker, D. A., Malcolm-Callis, K. J., Wiseman, M. W., \& Hallford, D. M. (2000). Effects of preshipping vs arrival medication with tilmicosin phosphate and feeding chlortetracycline on health and performance of newly received beef cattle. Journal of Animal Science. 78(2), 267-274.

Eeckhout, W., \& De Paepe, M. (1994). Total Phosphorus, Phytate-Phosphorus and Phytase Activity in Plant Feedstuffs. Animal Feed Science and Technology. 47(1-2), 19-29.Doi 10.1016/0377-8401(94)90156-2. http://dx.doi.org/10.1016/0377-8401(94)90156-2

Fernandez, J. A. (1995). Calcium and Phosphorus-Metabolism in Growing Pigs .2. Simultaneous Radio-Calcium and Radio-Phosphorus Kinetics. Livestock Production Science. 41(3), 243-254. http://dx.doi.org/10.1016/0301-6226(94)00064-E

Foote, R. H., Seidel, G. E., Hahn, J., Berndtson, W. E., \& Coulter, G. H. (1977). Seminal Quality, Spermatozoal Output, and Testicular Changes in Growing Holstein Bulls. Journal of Dairy Science. 60(1), 85-88. http://dx.doi.org/10.3168/jds.S0022-0302(77)83832-0

Garikipati, D., \& Kincaid, R. (2004). Effect of exogenous phytase on phosphorus digestibility in dairy cows and calves. Journal of Animal Science. 82, 118-118.

Geisert, B. G., Erickson, G. E., Klopfenstein, T. J., Macken, C. N., Luebbe, M. K., \& MacDonald, J. C. (2010). Phosphorus requirement and excretion of finishing beef cattle fed different concentrations of phosphorus. Journal of Animal Science. 88(7), http://dx.doi.org/10.2527/jas.2008-1435

GfE, G. f. E. (1995). Empfehlungen zur Energie- und Nährstoffversorgung der Mastrinder (Vol. 6),

Khan, S. A. (1978). Interaction of cooper and zinc and its influence on the metabolism of major nutrients in growing calves. . Ph.D., Nuslim University, Aligarh, India.

Khorasani, G. R., Janzen, R. A., McGill, W. B., \& Kennelly, J. J. (1997). Site and extent of 
mineral absorption in lactating cows fed whole-crop cereal grain silage or alfalfa silage. Journal of Animal Science. 75(1), 239-248.

Kincaid, R. L., Chew, B. P., \& Cronrath, J. D. (1997). Zinc oxide and amino acids as sources of dietary zinc for calves: Effects on uptake and immunity. Journal of Dairy Science. 80(7). 1381-1388. http://dx.doi.org/10.3168/jds.S0022-0302(97)76067-3

Kirchgessner, M., Heindl, U., \& Schwarz, F. J. (1994). Content and Deposition of Trace-Elements in Various Tissues and in the Empty Body of Growing German Simmental Bulls. Journal of Animal Physiology and Animal Nutrition-Zeitschrift Fur Tierphysiologie Tierernahrung $\quad$ 260-271. http://dx.doi.org/10.1111/j.1439-0396.1994.tb00395.x

Klosch, M., Ranft, S., Richter, G. H., \& Flachowsky, G. (1994). Effect of Phosphorus Repletion after P-Poor Feeding on Feed Intake, Live Weight Gain and Selected Parameters of Metabolism in Fattening Bulls. Deficient and Excessive Levels of Macroelements and Trace Elements in Nutrition. 680-685.

Kornegay, E. T., (2001). Digestion of Phosphorus and other Nutrients: the Role of Phytases and Factors Influencing their Activity. United Kingdom: CABI Publishing p.252.

Maenz, D. D. (2001). Enzymatic Characteristics of Phytase as they Relate to their Use in Animal Feeds (Vol. 1). UK: CABI Publishing.p.61-84.

Mandal, G. P., Dass, R. S., Isore, D. P., Garg, A. K., \& Ram, G. C. (2007). Effect of zinc supplementation from two sources on growth, nutrient utilization and immune response in male crossbred cattle (Bos indicus X Bos taurus) bulls. Animal Feed Science and Technology. 138(1), 1-12. http://dx.doi.org/10.1016/j.anifeedsci.2006.09.014

Mccarthy, J. F., Aherne, F. X., \& Okai, D. B. (1974). Use of Hcl Insoluble Ash as an Index Material for Determining Apparent Digestibility with Pigs. Canadian Journal of Animal Science. 54(1), 107-109. http://dx.doi.org/10.4141/cjas74-016

Millar, M. J., Fischer, M. I., Elcoate, P. V., \& Mawson, C. A. (1958). The Effects of Dietary Zinc Deficiency on the Reproductive System of Male Rats. Canadian Journal of Biochemistry and Physiology. 36(6), 557. http://dx.doi.org/10.1139/o58-062

Morse, D., Head, H. H., \& Wilcox, C. J. (1992). Disappearance of Phosphorus in Phytate from Concentrates Invitro and from Rations Fed to Lactating Dairy-Cows. Journal of Dairy Science. 75(7), 1979-1986. http://dx.doi.org/10.3168/jds.S0022-0302(92)77957-0

Neathery, M. W., Miller, W. J., Blackmon, D. M., Pate, F. M., \& Gentry, R. P. (1973). Effects of Long-Term Zinc Deficiency on Feed Utilization, Reproductive Characteristics, and Hair Growth in Sexually Mature Male Goat. Journal of Dairy Science. 56(1), 98-105. http://dx.doi.org/10.3168/jds.S0022-0302(73)85121-5

Pfeffer, E., Beede, D. K., \& Valk, H. (2005). Phosphorus Metabolism in Ruminants and Requirements of Cattle. United Kingdom: CABI publishing, Cambridge.p.195-231. 


\section{Macrothink}

Journal of Biology and Life Science ISSN 2157-6076 2014, Vol. 5, No. 1

Puchala, R., Sahlu, T., \& Davis, J. J. (1999). Effects of zinc-methionine on performance of Angora goats. Small Ruminant Research. 33(1). 1-8.Doi 10.1016/S0921-4488(98)00194-1. http://dx.doi.org/10.1016/S0921-4488(98)00194-1

Salama Ahmed, A. K., Cajat, G., Albanell, E., Snch, X., Casals, R. (2003). Effects of dietary supplements of zinc-methionine on milk production, udder helth and zinc metabolism in dairy goats. Journal of Dairy Research. 70. 9-17. http://dx.doi.org/10.1017/S0022029902005708

Scott, D., \& Buchan, W. (1985). The Effects of Feeding Either Roughage or Concentrate Diets on Salivary Phosphorus Secretion, Net Intestinal Phosphorus Absorption and Urinary Phosphorus Excretion in the Sheep. Quarterly Journal of Experimental Physiology and Cognate Medical Sciences. 70(3), 365-375.

Sunvold, G. D., \& Cochran, R. C. (1991). Technical Note - Evaluation of Acid Detergent Lignin, Alkaline Peroxide Lignin, Acid Insoluble Ash, and Indigestible Acid Detergent Fiber as Internal Markers for Prediction of Alfalfa, Bromegrass, and Prairie Hay Digestibility by Beef Steers. Journal of Animal Science. 69(12), 4951-4955.

Suttle, N. F. (2010). Minerals in livestock production. Asian-Australasian Journal of Animal Sciences. 13. 1-9.

Tapiero, H., \& Tew, K. D. (2003). Trace elements in human physiology and pathology: zinc and metallothioneins. Biomedicine \& Pharmacotherapy. 57(9), 399-411.Doi 10.1016/S0753-3322(03)00081-7. http://dx.doi.org/10.1016/S0753-3322(03)00081-7

Ternouth, J. H. (1989). Endogenous Losses of Phosphorus by Sheep. Journal of Agricultural Science. 113, 291-297. http://dx.doi.org/10.1017/S0021859600069963

Valk, H., Sebek, L. B. J., \& Beynen, A. C. (2002). Influence of phosphorus intake on excretion and blood plasma and saliva concentrations of phosphorus in dairy cows. Journal of Dairy Science. 85(10), 2642-2649. http://dx.doi.org/10.3168/jds.S0022-0302(02)74349-X

Van Laar, H., \& Jongbloed, A. W. (2010). Effect of zinc and copper on health and fertility in cattle Wageningen UR Livestock Research, Partner in livestock innovations. Wageningen UR: Livestock Research.

VDLUFA. (1997). Die chemische Untersuchung von Futtermitteln. Ergänzungslieferungen von 1983, 1988, 1992, 1997, 2004, 2006, 2007. VDLUFA-Methodenbuch. 3.

Vitti, D. M. S. S., Kebreab, E., Lopes, J. B., Abdalla, A. L., De Carvalho, F. F. R., De Resende, K. T., Crompton, L. A., \& France, J. (2000). A kinetic model of phosphorus metabolism in growing goats. Journal of Animal Science. 78(10), 2706-2712.

Williams, S. N., Lawrence, L. A., Mcdowell, L. R., Wilkinson, N. S., \& Warnick, A. C. (1991). Phosphorus concentrations in blood, milk, feces, bone and selected fluids and tissues of growing heifers as affected by dietary phosphorus. Livestock Research for rural Development. $3(2)$,

Winter, L., Meyer, U., Spolders, M., Hüther, L., Lebzien, P., \& Dänicke, S. (2013). Effect of 


\section{Macrothink}

exogenous phytase on the phosphorus balance of lactating cows fed a corn based diet. Journal of Biology and Life Science. 4(2), 232-250. http://dx.doi.org/10.5296/jbls.v4i2.3697

Wright, C. L., \& Spears, J. W. (2004). Effect of zinc source and dietary level on zinc metabolism in Holstein calves. Journal of Dairy Science. 87(4), 1085-1091. http://dx.doi.org/10.3168/jds.S0022-0302(04)73254-3

\section{Copyright Disclaimer}

Copyright reserved by the author(s).

This article is an open-access article distributed under the terms and conditions of the Creative Commons Attribution license (http://creativecommons.org/licenses/by/3.0/). 